\title{
Degrees of change toward polycentric transboundary water governance: exploring the Columbia River and the Lesotho Highlands Water Project
}

\author{
William Jesse Baltutis $^{1}$ and Michele-Lee Moore ${ }^{1,2}$
}

\begin{abstract}
Complex challenges emerging in transboundary river basins reveal a need to include a range of interests and actors in governance processes. Polycentric governance is one framework that can address this need and inform adaptive and resilient governance processes in transboundary basins as linked social and ecological systems. Here, we explore whether and how nonstate actors might be contributing to a shift in governance toward polycentric systems for the Columbia River (Canada/USA) and the Lesotho Highlands Water Project (Lesotho/South Africa). Using data gathered from 60 in-depth interviews, our empirical results illustrate four governance themes relevant to the emergence of polycentricity in the case study basins: authority, flexibility, coordination activities, and information sharing. Although the emergence of polycentricity is limited by existing state-centric governance regimes, these regimes show evidence that polycentric traits are supplementing existing governance systems, influencing policy processes, and introducing a range of management values.
\end{abstract}

Key Words: authority; Columbia River; coordination; flexibility; information sharing; Lesotho Highlands Water Project; polycentricity; transboundary water governance

\section{INTRODUCTION}

There is a growing trend in the governance of international transboundary waters, i.e., waters that cross nation-state borders, toward greater levels of participation by local, regional, and Indigenous governments, as well as nongovernmental actors (Lemos and Agrawal 2006, Norman and Bakker 2009, Chen et al. 2013, Norman 2014). These various actors seek a greater voice to address a number of challenges, including river basin development projects (Hirsh and Wyatt 2004), land- and wateruse decisions that affect a range of social, cultural, and spiritual values in a watershed (Flanagan and Laituri 2004), and the need to recognize the rights and self-determination of Indigenous peoples within watersheds (Osborn 2012, von der Porten and de loë 2013).

At the same time that this participatory shift is emerging in practice, scholars are recognizing the need to build socialecological resilience within watersheds (Hill Clarvis and Engle 2015, Hurlbert and Gupta 2016). These discussions concentrate on adapting, and even transforming, existing water governance approaches to respond to increasing challenges and to build capacity to govern better the dynamic nature of watersheds (Sneddon and Fox 2007, Armitage 2008, Berkes 2010, Cosens 2010, Akamani and Wilson 2011, Pahl-Wostl et al. 2012, Rijke et al. 2013, Bankes and Cosens 2014, Gunderson et al. 2017). Polycentric governance is one approach that is recognized for integrating multiple issues and actors across different jurisdictional and governance levels (Andersson and Ostrom 2008, Huitema et al. 2009, Ostrom 2010, da Silveira and Richards 2013, Warner et al. 2014).

The applicability of polycentric governance as a form of water governance has focused on analyses at national and subnational levels (Marshall et al. 2013, Thiel 2015, Knieper and Pahl-Wostl 2016), with a more limited examination of transboundary watersheds (Akamani and Wilson 2011, Myint 2012, da Silveira and Richards 2013). Actors at national and subnational levels have tested different forms of watershed governance, with histories of bioregionalism (McGinnis 1998, Cook et al. 2016), community-based approaches (Marshall 2007, Mitchell 2013), and catchment- or river basin-based authorities (Tarlock 2000, Suhardiman et al. 2012, Huitema and Meijerink 2017) in recent decades. To that extent, polycentric forms may become the most recent wave of governance reforms.

However, the governance of international rivers has long been dominated by state-based approaches (Conca 2005, Lankford and Hepworth 2010). Thus, the shift toward engaging nonstate or noncentral state actors in transboundary watersheds raises new questions in relation to polycentric governance. Specifically, there is a need to understand whether and how nonstate actors might be contributing to a change in governance toward polycentric systems. It is unclear whether and how polycentric governance can emerge in cases where top-down institutional arrangements have long been present and functioning (Lebel et al. 2005, Warner et al. 2014). Moreover, polycentric concepts have emerged primarily from a western body of scholarship that remains relatively silent in its consideration of the rights, title, and autonomy of Indigenous nations, and what this means for the possibility of polycentric governance emerging in practice.

To explore whether and how noncentral state actors might be contributing to a change toward polycentric systems in transboundary basins that are currently governed through centralized arrangements, we provide an empirical examination of two case studies: the Columbia and Orange-Senqu river basins. These basins are widely recognized for their successful transboundary water cooperation (Tarlock and Wouters 2007, Jacobs 2012). Further, as actors in each basin start to self-organize and gain increasing levels of governance autonomy and influence over management processes, these basins have the potential to be frontrunners in efforts to integrate a diversity of actors across multiple scales and sectors to include a range of interests and perspectives in river operations. This is relevant in the Columbia 
River basin, where Indigenous nations are reasserting autonomy and self-determination over resource management, including waters that are transboundary to the traditional territories of the Indigenous peoples and to Canada and the United States (Columbia Basin Tribes and First Nations 2015). It is also relevant in South Africa, where there is increasing awareness that local levels should be more involved in transboundary planning processes (Raddgever et al. 2008).

We begin with a review of the theoretical underpinnings of polycentric governance. Next, we explain our methods, including a brief history and geographical overview of the two case studies. We then present the empirical results, showing four governance themes that illuminate the extent to which the existing statecentric governance systems in the cases are shifting toward polycentric governance or not, and illustrate the challenges and opportunities for the emergence of polycentric governance systems within existing top-down, state-based systems. Although the emergence of polycentric governance systems appears limited in the cases we examine, existing state-centric governance regimes have become increasingly contested by the expansion of actors and initiatives at multiple levels into the realm of transboundary water governance and management. This result indicates that shifting toward polycentric governance may not occur in one rapid transformation; rather, it may occur more slowly, with degrees of change being observed.

\section{INTRODUCTION TO POLYCENTRIC GOVERNANCE}

A growing number of critiques state that existing water governance arrangements are increasingly unable to address the complexity and uncertainty that characterizes social-ecological systems today (Vörösmarty et al. 2000, Carpenter et al. 2011), including the challenges posed by climate change and competition for limited water supplies (Kranz and Vorwerk 2007, Cook et al. 2009, de loë 2009, Granit et al. 2012). Scholars have argued for innovation and transformative change in water governance to integrate diverse values, knowledge, actors, and interests better and to grapple with the complexity of the challenges being faced (Pahl-Wostl et al. 2010, Moore et al. 2014, Maclean and the Bana Yarralji Bubu Inc. 2015, Pahl-Wostl 2017). Many scholars propose that polycentric governance systems are best suited for this task (Huitema et al. 2009, Pahl-Wostl et al. 2010, 2012, Rijke et al. 2013).

Initially conceived by Polanyi (Polanyi 1951, as cited in Aligica and Tarko 2012), and further developed by Ostrom et al. (1961), the concept of polycentric governance has been used as a lens and guiding principle to analyze a diversity of management and governance issues, including common-pool resources (Ostrom 1990, McGinnis 1999, Mostert 2012), urban and regional planning (Salet and Savini 2015), decentralized regulatory regimes (Black 2008), forest governance (Nagendra and Ostrom 2012), and climate governance (Ostrom 2010, Jordan et al. 2015).

Within this body of scholarship, polycentric governance systems are understood to involve dispersed authority to separate and autonomous bodies or governing units with overlapping jurisdictions that operate under an overarching set of rules and that function in a coherent manner through self-organization (Ostrom et al. 1961, McGinnis 1999, Folke et al. 2005, Huitema et al. 2009, Ostrom 2009, Aligica and Tarko 2012, Cosens et al. 2017). These units can be organized geographically based on where they have an independent domain of authority (e.g., a river basin management agency cutting across jurisdictions), and can be linked horizontally around common issues with other independent units, while being nested vertically within broader governance units (Marshall 2007, McGinnis and Ostrom 2011, Biggs et al. 2012). The creation of overarching sets of rules illustrates the importance of coordination between the autonomous units, where the state can play a coordinating role within a nested system (e.g., where national legislation provides decentralized authority to noncentral state actors; Pahl-Wostl and Knieper 2014). The role of other actors in governance processes in no way indicates the end of the state as a significant site of regulation and stability (Marshall 2007, Reed and Bruyneel 2010). Instead, it reflects the evolution of governance in a complex, globalized, and multiscaled world (Scholte 2005).

Pahl-Wostl and Knieper (2014:147) posit that the emergence of polycentric governance systems results from the capacity of actors at multiple levels to self-organize "in combination with purposeful design". This is similar to what Marshall (unpublishedmanuscript) calls the "positive-feedback dynamics" that drive self-organizing processes in what are characterized as complex and adaptive systems (Garmestani and Benson 2013). However, empirical evidence that captures these general dynamics, and specifically, the experience of this emergent self-organizing process from the perspectives of those driving that dynamic in transboundary watersheds, needs further strengthening to truly understand how this theory plays out in practice. Given its self-organizing and dynamic nature and the fact that water governance is not "starting from scratch" in most basins (i.e., top-down, state-based governance is already present), questions remain regarding the emergence of polycentric transboundary water governance. Scholars such as Carlisle and Gruby (2019) have recognized that perhaps governance arrangements characterized as polycentric can only be presented in degrees, or along a spectrum, whereby governance may be "more or less polycentric" (Carlisle and Gruby 2019:21).

\section{Advantages and limitations}

In the existing literature, at least five key advantages are put forward for what polycentric governance systems could ideally achieve in practice (Duit et al. 2010, Morrison 2017; Marshall, unpublished manuscript). First, because of the large number of autonomous units at spatial and administrative scales, greater learning opportunities are believed to be able to emerge when the separate units experiment with new approaches, compared to the level of experimentation possible at any given moment in a single central authority (Brondizio et al. 2009, Huitema et al. 2009, Epstein et al. 2015). These learning opportunities can result when more interests are present, and units are exposed to different ideas and learn from one another. Second, polycentric governance systems are assumed to be able to provide room for local and traditional knowledge to be shared across the administrative scale so that decision-making processes can be more responsive to local interests (Marshall 2007, Galaz et al. 2012, Simonsen et al. 2014). Third, given that the individual governance units in a polycentric governance system are likely to be smaller than in a centralized system, it is assumed they may be able to respond more quickly to uncertainty and disturbances than a centralized authority focused on optimizing some limited aspect of an ecological system (Ostrom 1999, Cosens 2013), which can lead to system collapse 
(Walker and Salt 2012). In the case of water, the goal is often to optimize allocation for human uses. Fourth, scale-specific approaches can be used across the nested and linked set of units to address different ecological issues through "institutional fit" (i.e., the congruence between ecosystems and institutional arrangements; Epstein et al. 2015, Carlisle and Gruby 2019). Finally, polycentric governance systems can exhibit overlap, redundancy, and institutional density that is believed to enhance overall resilience (Morrison 2017, Carlisle and Gruby 2019).

Despite the promise of polycentric governance systems, scholars have indicated that such systems are not without challenges. First, the ideal version treats each group in a polycentric system as equal. In practice, however, power asymmetries may result in more powerful actors shaping governance structures to their own interests (Biggs et al. 2012, Morrison et al. 2017). Second, scholars have identified a need to balance redundancy and experimentation with the reality of costs incurred by coordinating, consulting, and negotiating trade-offs with members of multiple governance institutions to reach agreements (Biggs et al. 2012, Mostert 2012, Simonsen et al. 2014). In an era of scarce financial resources available for water governance, it is not clear if polycentric systems are financially feasible, and lowcost versions may not be able to meet the promise of coordination and inclusion. Third, scholars have found limited empirical evidence regarding the flexibility of polycentric systems, their ability to reflect local preferences better, or the greater extent to which experimentation and learning occurs as compared to centralized and hierarchically organized systems (Huitema et al. 2009, Morrison 2017). For example, the environmental governance system of Australia's Great Barrier Reef is characterized by polycentric arrangements, but the effectiveness to enhance environmental outcomes is not certain (Morrison 2017). Others have noted that systems may be polycentric but still remain rigid and inflexible, as evidenced in the Everglades socialecological system (Gunderson et al. 2017).

These debates about the promise and perils of polycentric governance are occurring alongside discussions about the challenges of existing transboundary water governance structures, which tend to be centralized (Conca 2005, Linton and Brooks 2011), and the growing understanding that these centralized systems need to change. As one example of this need for change, the state-centric frameworks that primarily govern transboundary watersheds have explicitly marginalized certain groups, including Indigenous nations, who have traditional territories in many transboundary basins (Earle and Neil 2017, Norman and Bakker 2017). It remains unclear whether polycentric governance can be a solution to the need for fundamentally different approaches to governing and cogoverning with Indigenous nations in centralized systems. Likewise, although polycentric governance is generally understood to include diverse actors, exactly which nonstate actors are being engaged in transboundary governance is not well established, thereby raising questions of governance for whom and by whom. The risk is that polycentric governance is simply another approach that will continue to reproduce patterns of marginalization. Furthermore, although state agencies, in theory, can coordinate between different units, thus serving one of the essential functions that connect different scales and levels of actors in polycentric governance systems, it is unclear if, in practice, the state is willing and able to fill this role. Most importantly, it remains uncertain whether and how a system can shift from a state-centric approach to a polycentric one, and whether this shift resolves some of the challenges of existing transboundary water governance structures.

\section{METHODS AND CASE SELECTION}

Given the exploratory nature of this work and the need to continue to develop empirically grounded conceptual understandings of polycentric governance, we used a grounded theory approach (Corbin and Strauss 2008). Grounded theory is concerned with "social processes or actions" that ask questions about "what happens and how people interact" (Sbaraini et al. 2011:129, emphasis original). The methodology works toward inductive theory building (Strauss and Corbin 1994, Chiovitti and Piran 2003). Here, we attempt to build a grounded, inductive theory about the emergence of polycentric governance by drawing on data and concepts that emerge across the two cases.

Given the interest in understanding whether and how polycentric governance systems may emerge, the case study selection was based on the following criteria.

1. Cases were previously recognized as "textbook examples" of successful forms of transboundary water governance and, therefore, were expected to be likely to continue as frontrunners for considering new forms of governance to respond to complex social-ecological challenges;

2. Preexisting evidence indicated the presence of noncentral state actors engaging in water governance processes (Norman and Bakker 2005, Meissner 2015, McKinney et al. 2016). Without this, the chances that polycentric governance might be emerging would be nonexistent; and

3. Preexisting evidence of on-the-ground activities indicated potential for changes in existing transboundary water governance processes.

The Columbia River Treaty has recently undergone a treaty review, and formal renegotiations have already begun for key aspects of the treaty (e.g., flood provisions, benefit sharing). The third dam of the multidam Lesotho Highlands Water Project is currently under construction, with further dam projects planned. Each basin, therefore, offers ongoing and timely processes that provide empirical grounding to explore the integration and coordination of actors, interests, and values into governance processes and to uncover whether a polycentric governance system, and the promise it holds, is emerging. Doing so has the potential to enable governance processes to respond better to the growing number of issues emerging for transboundary waters, such as a more equitable balance between water for human needs (e.g., hydropower, agriculture) and the environment, as well as the inclusion of a diversity of noncentral state actors in governance processes.

\section{Case study background}

Columbia River basin

From its origins in Columbia Lake near Canal Flats, British Columbia, Canada, the Columbia River travels approximately $2000 \mathrm{~km}$ to its mouth at the Pacific Ocean, near Astoria, Oregon, USA (Fig. 1). The entire basin covers $672,000 \mathrm{~km}^{2}$ within British 
Columbia and seven U.S. states (Idaho, Oregon, Washington, Montana, Nevada, Utah, and Wyoming; Cosens and Williams 2012). Situated along the vast length of the main stem of the river are 14 large multiuse dams (Northwest Power and Conservation Council, https://www.nwcouncil.org/reports/columbia-river-history/ hydropower) and many smaller hydropower dams, which provide critical base load power (upwards of $55 \%$ of the Pacific Northwest region's electricity; Northwest Power and Conservation Council, https://www.nwcouncil.org/reports/columbia-river-history/hydropower) and $49 \%$ of BC Hydro's total capacity (https://www.bchydro.com/ energy-in-bc/operations/our-facilities/columbia.html).

Fig. 1. Map of the Columbia River basin. Created by Hailey Eckstrand, 2017.

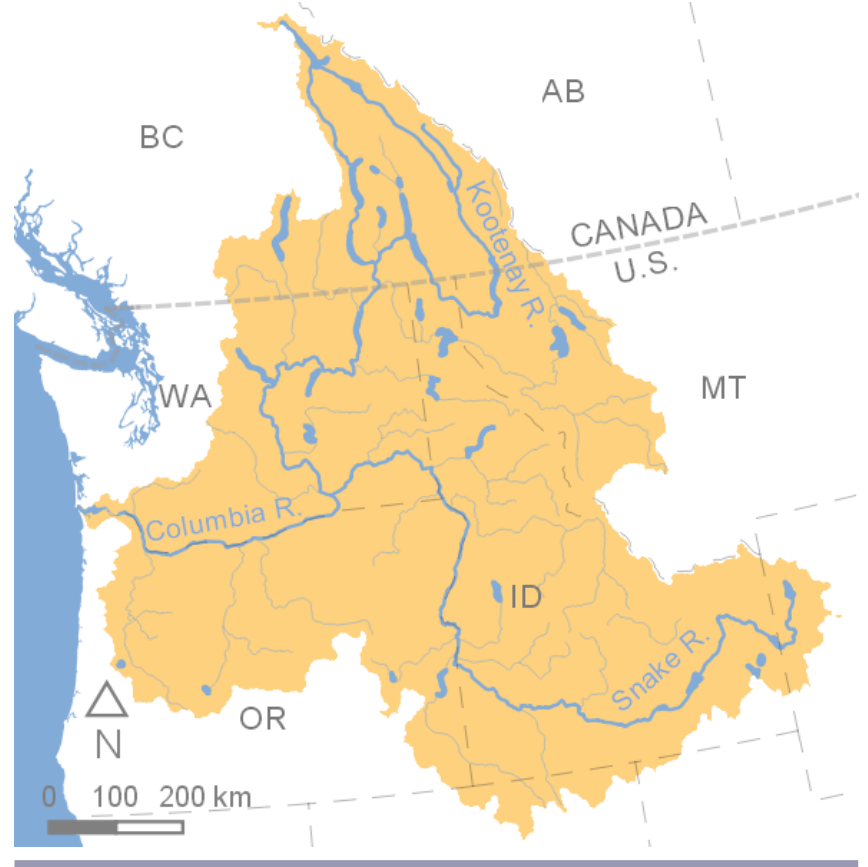

The Columbia River Treaty (the Treaty or CRT), which has governed the Columbia River since 1964, was negotiated between the Canadian and U.S. governments to reduce flood risk and optimize hydropower generation. A 1963 agreement between the Province of British Columbia (BC) and the Government of Canada gave most of the rights, obligations, and benefits of the Treaty to the province (Cosens and Williams 2012). The Treaty Entities tasked with implementing the CRT are BC Hydro for Canada and the Bonneville Power Administration and the U.S. Army Corps of Engineers in the United States. Flood control provisions are set to expire in 2024, and certain elements of the Treaty have been identified as up for renegotiation (e.g., Canadian entitlements). Between 2011 and 2013, Treaty Entities on both sides of the border have engaged in public consultation and a multiphase review process with the goal of informing the renegotiations, which formally began 29 May 2018. The review has provided an opportunity for historical injustices to be voiced and for First Nations (the term used for Indigenous peoples in the Canadian portion of the basin) and Tribes (the term used for Indigenous peoples in the U.S. portion) to engage in nation-tonation discussions with state, provincial, and federal governments.
It has been argued that the Treaty constitutes one of the most successful examples of an international water and benefit sharing treaty in the world (Hamlet 2011). However, the governance landscape has become increasingly complex since the 1964 ratification. Numerous social and ecological issues have emerged since 1964 (Bankes and Cosens 2014), including shifts in hydrology associated with a changing climate (McCaffrey et al. 2012). Future planning and governance in the basin must meet broader and more complex values and align diverse economic, political, and social agendas within ecological limits, beyond what a focus on hydropower and flood risk management can provide (Hirt and Sowards 2012, McKinney 2012). Further, a number of issues that were not considered during development of the original Treaty are contributing to the need for a more adaptable and collaborative governance framework, such as changes in empowerment of Indigenous and local communities (Cosens and Williams 2012).

\section{Orange-Senqu River basin and the Lesotho Highlands Water Project}

The Orange-Senqu River originates in the highlands of Lesotho and flows west for approximately $2300 \mathrm{~km}$ to its mouth at the Atlantic Ocean (Fig. 2; Heyns et al. 2008). It is the second largest river basin in southern Africa, behind the Zambezi, and has a catchment area of approximately 1 million $\mathrm{km}^{2}$ (Jacobs 2012b), making the basin larger than the Columbia River by approximately $330,000 \mathrm{~km}^{2}$. Lesotho, South Africa, Botswana, and Namibia are all riparian states, and the river forms the border between Namibia and South Africa along the last $600 \mathrm{~km}$ of its western reaches (Heyns et al. 2008). Lesotho and South Africa contribute the vast majority of mean annual flow to the river, at $41 \%$ and $55 \%$, respectively (Jacobs 2012a). The Orange-Senqu River is the most developed river in the southern Africa region, with 31 dams ( 24 in South Africa, 5 in Namibia, and 2 in Lesotho; Jacobs 2012b). It is also the most important river basin in South Africa; it contributes significantly to sustaining the mining, industrial, and agricultural activities of South Africa, as well as contributing to the waters needed in the mining and industrial heartland of Gauteng Province, a region that generates $10 \%$ of the economic output of the entire African continent (Heyns et al. 2008, Turton and Funke 2008, Jacobs 2012b). Much of this water comes directly from the Lesotho Highlands Water Project (LHWP), the largest interbasin transfer scheme in Africa (Heyns et al. 2008). The treaty governing the LHWP was signed between apartheid South Africa and a military regime in Lesotho in 1986.

Considered one of the few successful bilateral, cooperative, interbasin water transfer schemes in the world (Mirumachi 2007), the LHWP currently includes two dams and transfer tunnels (developed as part of Phase 1A and 1B). A third dam, the Polihali dam (Phase 2), is currently under construction. When it is completed, the waters behind the Polihali dam will submerge 5040 ha of land, of which an estimated 1125 ha is arable, and will displace 272 households from five completely submerged and five partially submerged villages (Lesotho Highlands Development Authority 2015). A wider community of people whose access to lands and resources will be significantly or permanently impeded will also be affected. The waters made available by the LHWP flow from Lesotho into South Africa's Vaal River, which is a major tributary of the Orange-Senqu River. This flow augments waters available behind the Vaal Dam, from which Gauteng Province withdraws much of its water (Heyns et al. 2008). 
Fig. 2. Map of the Orange-Senqu River basin. Used with permission from Andy Dean, Hatfield Consultants, 2018.

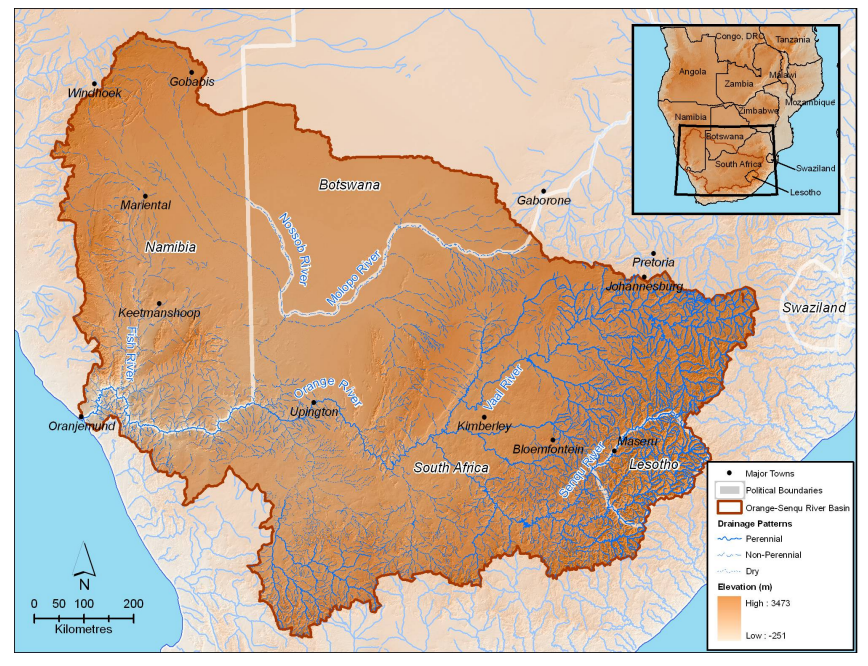

The Lesotho Highlands Water Commission was created to coordinate the overall LHWP (Mirumachi and Van Wyk 2010). Two other formal governance structures include the Lesotho Highlands Development Authority (LHDA) and the TransCaledon Tunnel Authority. These two structures are responsible for implementation and development of the infrastructure in Lesotho and management of the delivery tunnel that brings water to the Vaal River, respectively (Turton 2003).

\section{Data collection and analysis}

Over the course of two field seasons, first in the Canadian Columbia River basin (November 2015, January 2016), followed by South Africa and Lesotho (March-July 2016), 45 in-depth, semistructured interviews guided by open-ended questions (Dunn 2010) were conducted by the principal author (26 interviews in the Columbia River basin and 19 in the Orange-Senqu River basin). Approximately 15 further interviews with academics, practitioners, and experts were conducted to help build contextual understanding, for a total of 60 interviews across both basins. Initial contact with potential interviewees was made prior to arrival, with other key participants recruited through referrals (snowball sampling) and based on the need to test and refine emerging categories from data analysis (Schrieber 2001, Hay 2010). Interviewees included representatives from Indigenous-led organizations, the community, local government, nongovernmental organizations (NGOs), government ministries, academia and experts in the field, and the private sector, who were engaged in water governance processes in the case study basins. The interviews relied on probing questions to elicit rich details and descriptions, consistent with exploratory research strategies (Gerring 2004). Although each interview covered the same broad topics, the semistructured nature of the interview process allowed the principal author to explore areas of specific significance indepth and to clarify meanings and perspectives set forth by each interviewee. A digital recorder was used in the majority of interviews $(N=45)$, with consent from participants, and were transcribed verbatim.
In keeping with grounded theory methods, transcripts were manually coded in stages using a software data management tool (MaxQDA) to store and organize transcripts and emerging codes. The coding process distilled key themes, analyzed information collected, and informed further data collection (Cope 2010, Sbaraini et al. 2011). During the first-level coding of transcripts, codes were generated directly from the data, which were then reorganized into higher level categories by grouping similar codes together (Corbin and Strauss 2008). As categories emerged, further interviews were used to explore the limits of the categories, seeking to understand them in more detail (Dey 1999). These categories were grouped into theoretical themes, which were then tested and contrasted with key themes in polycentric governance literature. Empirical data were substantiated with analysis of academic literature, policy documents, grey literature, and media reports, as well as our own observations and experiences. The authors relied on deep critical reflection of the themes that emerged from the data through memoing, as well as multiple iterations of coding, to identify any biases and reflect on the emergence of categories.

\section{RESULTS: EXPLORING THE EMERGENCE OF POLYCENTRIC GOVERNANCE FOR TRANSBOUNDARY WATERS}

Based on the analysis, we identified four key themes as relevant to exploring whether and how nonstate actors might be contributing to shifts in governance toward polycentric systems in transboundary basins that are currently characterized as conventional and state centric. These themes were: "locked-in" authority arrangements, existing and emerging forms of flexibility, novel collaboration activity, and cross-scale information sharing.

\section{Locked-in authority arrangements}

Social systems may exhibit inflexibility and rigidness to adaptation, whereby conventional resource management by command and control, with authority limited to a few actors, becomes locked-in (Allison and Hobbs 2004, Carpenter and Brock 2008). This circumstance is known as institutional path dependence, whereby current institutional arrangements reduce opportunities for institutional reforms (North 1991, Marshall and Alexandra 2016). In our cases, we found that authority remains locked-in with state-based agencies and actors focused on economic benefits from the rivers, particularly hydroelectric production, which have defined the conventional and centralized approaches to transboundary water governance in the two basins. For the Columbia River, the sole transboundary entity is the Permanent Engineering Board. It has a narrowly defined mandate that gives it authority over collecting flow records, settling differences between the Treaty Entities, and creating annual reports (https://www.nwd.usace.army.mil/CRWM/PEB/). Consequently, the Permanent Engineering Board primarily focuses on technical and operational matters pertaining to the management of the Columbia River. With such a narrow mandate, the Permanent Engineering Board arguably lacks the legal authority to address basin-wide social-ecological issues in a holistic sense, and this is widely seen as a significant governance limitation by actors in the basin. For example, one participant from a watershed organization in the Canadian portion of the basin argued,

It's not just about money, it's not just about hydro, it's not just about flood control. I think there has to be 
operational entities that are involved in Treaty and water distribution decisions that need to be broader than just the group that we have in place right now... We have to have environmental thinkers and other thinkers that can participate effectively in operational concerns. (Participant CB10S62).

Recognition of the limitations, and wanting to develop deeper coordination between various interests and actors in the Canadian portion of the basin, including local governments, First Nations, provincial and federal government, BC Hydro, and citizen groups, led to the establishment of the Columbia Basin Regional Advisory Committee (CBRAC). Facilitated by the Province of $\mathrm{BC}$, CBRAC emerged from public consultation conducted by the Province for the Treaty review as a way to continue the engagement of various actors and to provide input into BC Hydro's operation of the Columbia system. However, the Committee has no decision-making authority. As one CBRAC member explained,

We have no authority... If we have concerns right now in this area, it's going to end up on the [Ministry of] Mines and Energy desk. It isn't going to end up in some common forum from both the U.S. and BC side of the equation. (Participant CB4S22).

Although CBRAC aims to be representative of community interests to ensure that governments hear the local voices, the CRT and the associated governance structures and processes do not provide a legal mandate to subnational groups such as CBRAC. Therefore, although the top-down authorities have recognized the need to create new units to enhance activities across scales, the data suggest that participants perceive formal authority to remain within government agencies.

Similar to the Columbia River, formal governance authority for the LHWP is held by state agencies and government ministries. As mentioned, the LHDA and Trans-Caledon Tunnel Authority are the two entities charged with implementing the LHWP in Lesotho and South Africa, respectively, with overall project coordination by the Lesotho Highlands Water Commission. Although the Commission comprises representatives from Lesotho and South Africa, participants perceived there was limited room for other actors to play a formal role in decision making. For instance, one interviewee argued,

Ultimately, the power resides within the Ministers of water in both of those states, the implication of which is a large amount of discretionary influence [residing] in a single individual. It also focuses very much on water, as opposed to the bigger development implications. And it also creates a very strong sort of hierarchy. (Participant OS19S47).

Nationally, South Africa has set out to create Catchment Management Agencies and Water User Associations across the country to bring decision-making processes and water resource management to a localized level (Förster et al. 2017). However, to date, only two Catchment Management Agencies have been fully established, the Inkomati-Usutu and the Breede-Gouritz, and in the case of the Inkomati-Usutu Catchment Management Agency, it took almost ten years to transfer key legislative mandates to the agency (Denby et al. 2016). Moreover, authority for transboundary waters, including the LHWP, is still firmly situated with central government ministries. For instance, an interviewee with the partially established Vaal River ProtoCatchment Management Agency (currently residing in the Department of Water and Sanitation) argued s/he has not been involved in decision-making processes for the project, stating:

What should happen, which has not happened, is that we
in the Vaal should be part and parcel of the international
institution between... South Africa and Lesotho. Those
institutions are there, but I personally have not been
involved... We believe that because the water from
Lesotho highlands enters South Africa into my
catchment, we should play a major role in decision
making there. (Participant OS2S25).

In Lesotho, participants from affected communities, NGOs, and regional governments and organizations such as the Mokhotlong Community Area Liaison Committee reported some opportunities for input into decision-making processes for Phase 2 of the LHWP. A compensation program developed for affected communities in Lesotho was one of the few spaces in which local actors had the opportunity to provide feedback on drafts of the compensation policy and contest the timescale and amounts of compensation offered by the LHDA. However, this claim of greater participatory processes was disputed by other study participants living in communities soon to be relocated by the rising waters of the Polihali reservoir and by a participant working for a human rights $\mathrm{NGO}$ active in the region. For example, the latter participant explained,

You cannot call it consultation or public participation
because the way they (LHDA) conducted it. The LHDA
actually [came] up with a draft to the communities...
And if you can look at that, most of the issues [from the
communities] they do not accept. (Participant OS14S46).

Therefore, the findings suggest that most participants perceive decision-making authority as remaining in the purview of statebased actors.

The results indicate that in both the LHWP and the CRT, initiatives are emerging that are attempting to raise the profile of a diversity of interests. However, authority remains in the preexisting governance structures. Thus, these groups operate alongside state-centric governance structures. This status creates ongoing constraints for local actors. For example, even though the establishment of Catchment Management Agencies in South Africa has been described as a "textbook approach" to polycentric governance (Muller 2012), the balance of decision-making authority for transboundary rivers appears to be retained by the state. In the Columbia River, although a range of actors is involved in management issues (e.g., fisheries), and the Treaty review included comprehensive public consultation and nationto-nation discussions among federal, provincial, state, and Indigenous nations, the ultimate authority to renegotiate the CRT remains state based.

\section{Existing and emerging flexibility}

Despite the narrow focus of the CRT, participants perceived the existing governance and management arrangements in the basin as flexible. One participant explained how flexibility was built into the original treaty and has since been used to address ecological concerns that have developed over time. 


\begin{abstract}
The Treaty writers... left flexibility in the treaty for us... We've used that flexibility... [in] the initial nonpower uses agreements back in the 1990s. It's been an annual agreement since then, but it was one that we actually agreed to deviate from the strict Treaty operations because both sides needed some changes for fish. (Participant CB21S21).
\end{abstract}

The flexibility is achieved through supplemental agreements such as the Non-Treaty Storage Agreements referred to in the above quotation, which allow for the dam system operations to consider other benefits and interests beyond maximizing hydropower production (Columbia River Treaty Local Governments' Committee and Columbia Basin Trust 2015). As another example, the Libby Coordinating Agreement recognizes fish and fish management as an equal part of the operation of Libby dam, the fourth dam constructed under the CRT on the Kootenai River in Montana (McKinney et al. 2016). Participants identified that these kinds of agreements illustrate the ways in which actors with interests beyond hydropower have influenced dam operations on the Columbia River, and the flexibility within the Treaty to respond to these concerns.

Participants identified Water Use Plans developed by BC Hydro for the Canadian Columbia River system as representing an additional mechanism designed to increase flexibility for operations to balance competing uses of water. Water Use Plans were developed between 2000 and 2004 in consultation with provincial government agencies, First Nations, local residents, and interest groups. They resulted in recommendations on how changes to operations of the dams might have positive impacts on a variety of interests, including fish and wildlife, heritage, and recreation (Province of British Columbia 2013). As an interviewee who was previously employed by BC Hydro explained,

\begin{abstract}
We tried to get a cross-section of stakeholders to come in and basically sit around the table a number of times and look for a better way [for the]... changes that [BC $H y$ dro $]$ needed to make in the operations of our reservoirs to improve the overall well-being of $B C$. So, if we needed to give up some power so that there could be a better fishspawning regime or a better recreational regime, that was definitely on the table. (Participant CB12S8).
\end{abstract}

The implementation of Water Use Plans for the Columbia River cannot contravene the Treaty by compromising flood control and power generation (Province of British Columbia 2013). Moreover, Water Use Plans were developed in consultation with Indigenous nations, but not in a collaborative or co-led process. Thus, Water Use Plans do provide flexibility for BC Hydro to achieve unilateral operational changes in the system to meet a wider set of interests (i.e., do not require mutual agreement with the U.S. Treaty Entities). However, Water Use Plans are not taking on alternative forms to address existing gaps in the governance system around recognizing the rights, title, and autonomy of Indigenous nations.

Flexibility in operations for Phase 2 of the LHWP are less clear, given the ongoing construction of the Polihali dam and related water transfer infrastructure. However, participants indicated that under Phase 2, water transfers to South Africa may not be constant (as they are under Phase 1), and will allow for more flexibility to account for interests downstream of the dams along the Orange-Senqu River. However, an interviewee with a large water-using industry in South Africa noted,

\section{I think there is a bit of a trade-off discussion happening at the moment between the governments as to whether there can be more flexibility around the water, and it could come down to trading energy and water. (Participant OS18S12).}

Regarding trading energy and water, Article 7 (2) of the 2011 Phase 2 Agreement for the LHWP stipulates that the operation of Phase 2 shall ensure "the most advantageous options for the long term energy security of Lesotho without diminishing the benefits derived from the water delivery system". In the event that South Africa requires an optimal transfer of water from Phase 2 facilities that results in a loss of power generation in Lesotho, South Africa would compensate for the loss of these benefits "either in kind or in monetary value" (Lesotho Highlands Development Authority 2011). Further, similar to the flexibility in system operations for the Columbia River, an official with the Lesotho Highlands Water Commission indicated that Phase 2 may include the flexibility needed to ensure that water flows downstream of the dams can be changed to meet the interests of stakeholders, the river, and the environment (participant OS12S52). This situation might suggest that the allocation of water for downstream benefits and environmental interests under the 2011 Agreement has been shaped by a wider range of interests and objectives beyond a narrow focus on water transfers and hydropower production, even if the governance and management for Phase 2 will not be decentralized to local actors.

\section{Novel collaboration of local activities}

Although formal governance authority for the Columbia River is vested in the Treaty Entities in Canada and the United States, there are initiatives emerging at regional levels to coordinate activities across the border. These initiatives take a broader, basinwide approach to consider key water governance challenges. Two regional entities specifically attempting to bridge various levels of government and facilitate coordination between nonstate actors are the Columbia Basin Trust (Canada) and the Northwest Power and Conservation Council (United States). Although fragmented by the international border, each of these entities takes a regional perspective in the support of community, conservation, and energy initiatives, as well as knowledge generation. Both the Columbia Basin Trust and the Northwest Power and Conservation Council are formal in that they represent local interests in their respective parts of the basin, and are funded, authorized, and mandated through legislation, i.e., the Columbia Basin Trust Act (1996) and the Northwest Power Act (1980). However, neither entity has any authority to formally coordinate activities at an international level. To work around this constraint, the Columbia Basin Trust and the Northwest Power and Conservation Council have a memorandum of understanding for cooperation, signed in 2000 and renewed in 2011 (Columbia Basin Trust and Northwest Power and Conservation Council 2011).

For example, the Columbia Basin Trust and Northwest Power and Conservation Council hold yearly in-person meetings and host various transboundary initiatives such as a burbot fisheries research project in Lake Koocanusa and a climate change impacts 
study for the upper Columbia River (Northwest Power and Conservation Council 2015). However, as one member of one of the organizations explained, barriers remain to having a formal transboundary approach to collaborative planning or decision making.

Probably the only real barrier is that no one has legal authority to go further. We have very specific authority to do what we do... [and] are not really authorized to do any thing more... It seems like whenever we run up against doing more than just sharing information and sharing outreach, [government] starts to get jealous of their own authority. (Participant CB15S21).

Beyond these two organizations, Columbia Basin First Nations and Tribes are self-organizing collaborative cross-border initiatives. For example, the Canadian Columbia River Intertribal Fisheries Commission and the U.S.-based Columbia River InterTribal Fish Commission coordinate across the border to develop integrated approaches to fish reintroduction and restoration of fish passage. As an interviewee explained, collaborating on developing this initiative involved the following:

...work[ing] with U.S. Tribes and Canadian First Nations to develop the fish passage plan, and that plan reflects 15 U.S. Tribes and three Canadian First Nations coming together around a joint comprehensive work plan for salmon restoration... developed principally in the context of discussions around potential renewal of the CRT. (Participant CB19S14).

Through their collaborative work, the two organizations have maintained that, "restoring fish passage and reintroducing anadromous fish should be investigated and implemented as a key element of integrating ecosystem-based function into the Treaty" (Columbia Basin Tribes and First Nations 2015:2).

In the case of the Orange-Senqu, there are less novel collaborative forms emerging, but some limited coordination of large water users is occurring. The Stakeholder Operating Forum for the Vaal River System Annual Operating Analysis involves a wide range of large water users in South Africa, organized by the Department of Water and Sanitation to update water consumers on system operations. Unlike the Water Use Plans for the Columbia River in $\mathrm{BC}$, the Stakeholder Operating Forum is an ongoing (biannual) consultative process that enables input from water users and, thus, illustrates the emergence of an information sharing mechanism in South Africa. The Forum and the Operating Analysis for the Vaal River appears to support the centralized governance system by providing operational recommendations to meet a variety of interests and values in the basin. To that end, a degree of influence has resulted from coordination among different actors across sectors.

There is a history of coordinated activity between international and domestic NGOs in Lesotho and South Africa focused on antidam advocacy and monitoring of the adverse social and ecological effects resulting from the building of the LHWP (Khagram 2004, Meissner 2015). For instance, an interviewee with a large international organization argued, "having looked at it over the last 10 or 20 years, there is definitely a strong nongovernmental process in the country, advocating for the rights of those potentially affected by the project" (participant
OS19S26). This eventual coordinated effort put increased pressure on the World Bank to halt or postpone the project given the ongoing environmental and social concerns. According to one interviewee, there has been increasing pressure on the Lesotho Highlands Water Commission and LHDA to improve the substance and implementation of the compensation program for resettled communities between the phases of the project. Though the influence of both domestic and international NGOs and interest groups was not sufficient to halt the projects, it did contribute to the globalization of new norms about large dam development (Meissner 2015). This normative change includes no longer viewing dams as the only path to secure greater water supplies for a growing society, at the expense of local communities and the environment, when cheaper alternatives like water demand management could potentially meet increasing water requirements (Meissner 2015).

\section{Information sharing across scales}

With the emergence of new structures that are, albeit, limited in formal authority but which have contributed to the creation of flexible instruments and novel collaboration, participants also highlighted the emergence of cross-scale information sharing. For example, in the Columbia Basin, the CBRAC meetings have been described as "information transfers" (participant CB3S122), and one member described the context of the organization as follows:

...there is an expectation or a hope that the members of
CBRAC will take the information that we are getting
[from others in the committee] back to our communities
and discuss it with people in our communities so that [...]
if there are other people in [my community] that have a
value or a message that they would like brought forward,
then I would take that to CBRAC to try and engage a bit
more broadly in regard to what is going on with the Treaty
review. (Participant CB8S23).

Given the diversity of participating members and agencies (including BC Hydro and the BC Ministry of Energy and Mines), information sharing has been a key component of CBRAC's activities, including identifying opportunities to influence policy direction for the Treaty. An interviewee with the Northwest Power and Conservation Council in the United States explained:
I have actually done a briefing for the staff at the [BC] Ministry of Energy and Mines [...] on the power plan and fish and wildlife stuff we have done... [we've] had some of the BC provincial staff down here [and] our staff gave them a briefing on some of these things... Often it's about making sure they know what we are doing with power planning, and we know what BC Hydro is going to be doing with energy resources and things like that. (Participant CB15S17).

The information sharing initiatives described above have helped establish professional connections and interpersonal relationships and encouraged the diffusion of information. However, these initiatives have been limited to informal and ad hoc collaboration between Canadian and U.S. groups working on Columbia Riverrelated issues such as energy and fish and wildlife.

For communities affected by the LHWP in Lesotho, participants perceived there was limited information sharing and consultation between the LHDA and local communities on project 
development. This lack was most evident with the drafting of the compensation policy, identified as a critical issue that constrained wider engagement of local communities and individuals. As argued by an NGO worker in Mokhotlong District in Lesotho, "I think [the LHDA] is trying to ensure NGOs are not getting that information to digest and then try to fundraise elsewhere so that they should come and build capacity of the concerned communities" (participant OS14S68). Data revealed that the activities of the LHDA could be strengthened to ensure active participation by local communities in decision-making processes for development of the compensation policy.

\section{DISCUSSION}

We set out to explore whether and how noncentral state actors might be contributing to a change in governance toward polycentric systems in transboundary basins that are currently governed through centralized arrangements. The four themes that emerged from our analysis illustrate the complexity and difficulty of determining the extent to which (as a matter of degree and configuration) polycentric governance systems might be emerging, and whether any of the challenges associated with centralized systems are being addressed through that process.

Locked-in authority: In both cases, our results show that formal governing authority remains vested in state agencies and government ministries, with other values and interests such as ecosystem health considered subordinate to hydropower, flood risk management, and water transfer objectives. Although authority may remain centralized to facilitate economic growth and security resulting from hydropower, flood risk management, and water diversion regimes, our findings illustrate that incremental changes to other key aspects of governance may result in additional interests being represented and new actors being provided a space to engage. These findings indicate that rather than whole-system change occurring forthright, elements of polycentric transboundary water governance may emerge through observable, incremental changes. However, incrementalism illustrates the slow pace at which these challenges are being addressed, particularly with regard to recognizing the authority, rights, and title of Indigenous peoples on both sides of the boundary.

Existing and emerging flexibility: The literature on polycentric governance systems suggests that flexibility, experimentation, response diversity, and redundancy in the system are necessary for responding to change and uncertainty (Pahl-Wostl and Knieper 2014, Simonsen et al. 2014). To this end, evidence from both basins indicates flexibility is functioning, albeit to different degrees. In the Columbia River basin, agreements beyond the Treaty (e.g., Libby Coordinating Agreement) provide a measure of flexibility for operational concerns to meet additional interests, and ongoing efforts to reintroduce fish and restore habitats are occurring on both sides of the border. For Phase 2 of the LHWP, once the Polahali dam is completed, it will be operated to meet downstream environmental interests while providing a degree of flexibility for water releases (Lesotho Highlands Development Authority 2011). Therefore, even without authority being granted to numerous autonomous units in the form of "true" polycentric governance, flexibility among actors and within operations occurs alongside and as part of existing centralized structures. Governing arrangements have become more polycentric de facto, despite remaining subservient to treaty objectives that have relied on clear rules for dividing resources and benefits de jure, and not necessarily for adapting to change (Cosens 2010, Cosens et al. 2014). Despite the locked-in authority arrangements, observable and incremental change is occurring toward governance elements that, de facto, can be characterized as emerging polycentric governance.

Novel collaboration: Coordination among different, often overlapping, centers of authority and responsibility is critical to ideal polycentric governance systems because, without coordination, there can be a loss of effectiveness (Pahl-Wostl and Knieper 2014). Our findings show that coordinated initiatives are emerging in the Columbia River basin, mainly through novel collaborations that have adopted a basin-wide perspective. These collaborations are influencing the management of the river and have resulted in a range of issues being addressed that are not currently addressed by the transboundary regime (e.g., salmon reintroduction to the upper basin). In turn, this interaction has influenced the ongoing discussions about Treaty modernization and governing arrangements. However, influence is not the same as authority. In the case of Indigenous nations, these collaborations may indicate that a degree of polycentric governance is emerging, but it has still not addressed the need for structures that are predicated on the rights, title, and authority of Indigenous nations.

The nature of the coordinated activities between government entities (e.g., Lesotho Highlands Water Commission, LHDA, Trans-Caledon Tunnel Authority), and international organizations (e.g., World Bank, African Development Bank) involved in the financial components of the LHWP, and collaborative initiatives such as the Stakeholder Operating Forum for the Vaal River System Annual Operating Analysis in South Africa, would suggest that elements of coordination exist. However, these activities remain limited to the centralized actors and organizations, including large water users (e.g., water districts, energy companies), who arguably already hold power to influence the preexisting system. There is limited evidence to suggest ongoing coordinated activities between decentralized actors on governance issues for the LHWP in Lesotho.

These results show the variability in whether and how polycentric systems may emerge in transboundary watersheds. The Columbia case shows that novel collaborations can lead to the types of coordination that seem to align with the theory, whereas the Orange-Senqu case demonstrates that coordination can remain firmly in the hands of state-based institutions. In this way, our results show that while polycentric governance may require coordination, coordination itself does not guarantee that polycentric governance is emerging.

Information sharing: Information sharing is critical for learning, experimentation, and building capacity to engage in governance processes and to address effectively the complexity and uncertainty that is affecting the social-ecological resilience of watersheds. The results are again variable. The Columbia case indicates that the information sharing needed for effective coordination in a polycentric governance system is emerging, albeit in an ad hoc manner thus far. Deliberate initiatives have been set up in the LHWP, such as the Stakeholders Operational Forum and the participatory processes for the compensation 
program, which could easily be interpreted as indications of information sharing. However, participants perceived that information sharing remains quite constrained in practice and is a source of frustration for community and NGO participants wishing to have a role in developing the compensation program for communities impacted by Phase 2 of the LHWP.

\section{CONCLUSIONS}

Overall, our results show a complex picture regarding polycentric governance systems in transboundary watersheds. Our findings show that in the Columbia River and the LHWP, there is some emerging, albeit limited, evidence of polycentric governance, with the presence of flexible structures and processes to address emerging social-ecological challenges, novel collaborations, and information-sharing mechanisms between actors at different levels. The results of these initiatives are influencing transboundary policy processes and introducing other management values beyond the original mandates of the international treaties.

Globally, there is a trend toward a wider range of interests and objectives being represented in water governance (Conca 2005). This trend indicates a greater awareness of interests beyond hydropower production and suggests that other interests and actors are engaging and coordinating with one another in governance processes that once used to be the sole domain of centralized governments. The result is an ability to influence the direction of transboundary water governance and management (Baltutis et al. 2018). Although this result may not be unique to polycentric governance, it remains a characteristic of the emergence of polycentric transboundary water governance.

However, these signals of limited, emergent polycentric governance are, at this stage, supplementing existing state-centric governance regimes, rather than supplanting them. Accommodation of other interests has occurred in the management of the rivers, but only within state-centric governance regimes. With current governance processes able to accommodate a wider set of interests and values, decision-makers may be more reluctant to introduce greater shifts in authority toward decentralized, subsidiarity, or nested governance. That is, the presence of some aspects of polycentric governance, which have already emerged in the basins, may hinder later important shifts, including dispersed authority. However, the absence of a shift in governance authority to local actors does not mean the absence of policy influence. Indeed, the activities of local actors in both basins, albeit to different degrees, have helped shape the management regimes (Galaz et al. 2012, Carlisle and Gruby 2019). Regardless of degree, it remains unclear whether polycentric governance would address key concerns regarding the autonomy of Indigenous nations. While the ideal system recognizes autonomous units, it is unclear how the specific rights and title of Indigenous nations could be treated as distinct from other units.

It was not clear in our study if Indigenous nations in the Columbia River basin are even calling for a system of transboundary governance built on polycentric ideals for the river. Indigenous nations have been fighting to have their inherent and, in some cases, treaty-protected rights and title recognized by colonial governments for more than 150 years in the Pacific Northwest. In the traditional lands and waters of Indigenous peoples, dispersal of authority to an even greater number of non-
Indigenous actors, as in a polycentric system, is extremely problematic. A critical question then remains: Are there configurations of polycentric governance that better support the recognition of the rights and title of Indigenous peoples in the Columbia River basin? Suggesting that other non-Indigenous and nongovernment units in a system should gain equal power over issues where Indigenous peoples have rights and title does not necessarily benefit efforts toward reconciliation or adequately acknowledge the historical context in which transboundary water governance processes are taking place.

Emerging polycentric governance for transboundary waters where state-centric regimes exist de jure presents complex challenges in practice. Despite the potential benefits of polycentric governance systems, the literature does not clarify how state-based systems may actually transition toward polycentric arrangements. Our study demonstrates that transitions toward polycentric systems may not occur in a single instance or uniformly across the governance system. For instance, authority remains de jure with state-based actors for both the CRT and LHWP and is not dispersed to autonomous bodies (such as CBRAC), as the theory on polycentricity would suggest.

As previous scholarship has found (see Norman and Bakker 2009), processes of rescaling governance of transboundary waters downward to the local level are especially challenging if capacity at lower scales is limited. However, in both basins, there is an increase in engagement of noncentral state actors, including Indigenous nations involved in CRT review and large water users participating in decision-making processes for the Vaal River, compared to when the Columbia River and LHWP treaties were first signed. These broader levels of engagement and participation would remain consistent with how polycentric governance is understood in the literature (Thiel 2016) but, alone, do not constitute polycentric governance.

Thus, our findings suggest a slow transition away from state-based governance systems, with the state still retaining authority and a central role. This confirms what the literature suggests is a continued, although reconstructed, role of the state in a polycentric governance system (Warner et al. 2014). The continued role of the state is also interesting for discussions on what "authority" actually looks like for actors in a polycentric system, the degrees to which authority is exercised, and the different forms it takes when other actors wield power (in its different forms) in a governance system.

Responses to this article can be read online at: http://www.ecologyandsociety.org/issues/responses. php/10852

\section{Acknowledgments:}

We gratefully acknowledge comments received from Dr. Stephen Tyler, Dr. Michael Webb, and two anonymous reviewers. We also thank Laura Brandes for excellent editing assistance. The results presented here are one aspect of the work of ReFresh: Canada-U. S. Transboundary Water Governance and the Columbia River Treaty Renegotiations, funded by the Water Economics, Policy and 
Governance Network (WEPGN). Additional funding was provided by the Centre for Asia-Pacific Initiatives (CAPI) and the Borders in Globalization (BIG) Project, both at the University of Victoria. The principal author was a SSHRC Doctoral Scholar, a Graduate Fellow of the Centre for Global Studies, and a Graduate Fellow of the Borders in Globalization (BIG) Project. We thank all the individuals in Canada, USA, South Africa, and Lesotho who shared their perspectives and passion for their home waters and for welcoming the lead author into their communities and households. We give a special thank you to the community of water scholars at the Council for Scientific and Industrial Research (CSIR) in Pretoria, who helped the principal author immensely in his field research. All omissions and errors are of the authors alone.

\section{LITERATURE CITED}

Akamani, K., and P. I. Wilson. 2011. Toward the adaptive governance of transboundary water resources. Conservation Letters 4(6):409-416. https://doi.org/10.1111/j.1755-263X.2011.00188. $\underline{x}$

Aligica, P. D., and V. Tarko. 2012. Polycentricity: from Polanyi to Ostrom, and beyond. Governance 25(2):237-262. https://doi. org/10.1111/j.1468-0491.2011.01550.x

Allison, H. E., and R. J. Hobbs. 2004. Resilience, adaptive capacity, and the "lock-in trap" of the Western Australian agricultural region. Ecology and Society 9(1):3. [online] URL: http://www.ecologyandsociety.org/vo19/iss1/art3/

Andersson, K. P., and E. Ostrom. 2008. Analyzing decentralized resource regimes from a polycentric perspective. Policy Sciences 41(1):71-93. https://doi.org/10.1007/s11077-007-9055-6

Armitage, D. 2008. Governance and the commons in a multi-level world. International Journal of the Commons 2(1):7-32. https:// doi.org/10.18352/ijc. 28

Baltutis, W. J., M.-L. Moore, and S. Tyler. 2018. Getting to ecosystem-based function: exploring the power to influence Columbia River Treaty modernization towards ecosystem considerations. International Journal of Water Governance 6:43-63. http://dx.doi.org/10.7564/18-IJWG134

Bankes, N., and B. Cosens. 2014. Protocols for adaptive water governance: the future of the Columbia River Treaty. Monk School of Global Affairs, Toronto, Canada. [online] URL: http:// gordonfoundation.ca/app/uploads/2018/05/2014 POWI Protocolsfor-Adaptive-Water-Governance-Final.pdf

Berkes, F. 2010. Devolution of environment and resources governance: trends and future. Environmental Conservation 37 (4):489-500. https://doi.org/10.1017/S037689291000072X

Biggs, R., M. Schlüter, D. Biggs, E. L. Bohensky, S. BurnSilver, G. Cundill, V. Dakos, T. M. Daw, L. S. Evans, K. Kotschy, A. M. Leitch, C. Meek, A. Quinlan, C. Raudsepp-Hearne, M. D. Robards, M. L. Schoon, L. Schultz, and P. C. West. 2012. Toward principles for enhancing the resilience of ecosystem services. Annual Review of Environment and Resources 37:421-448. https:// doi.org/10.1146/annurev-environ-051211-123836

Black, J. 2008. Constructing and contesting legitimacy and accountability in polycentric regulatory regimes. Regulation \& Governance 2(2):137-164. https://doi.org/10.1111/j.1748-5991.2008.00034.
Brondizio, E. S., E. Ostrom, and O. R. Young. 2009. Connectivity and the governance of multilevel social-ecological systems: the role of social capital. Annual Review of Environment and Resources 34:253-278. https://doi.org/10.1146/annurev.environ.020708.100707

Carlisle, K., and R. L. Gruby. 2019. Polycentric systems of governance: a theoretical model for the commons. Policy Studies Journal, in press. https://doi.org/10.1111/psj.12212

Carpenter, S. R., and W. A. Brock. 2008. Adaptive capacity and traps. Ecology and Society 13(2):40. [online] URL: http://www. ecologyandsociety.org/vol13/iss2/art40/

Carpenter, S. R., E. H. Stanley, and M. J. Vander Zanden. 2011. State of the world's freshwater ecosystems: physical, chemical, and biological changes. Annual Review of Environment and Resources 36:75-99. https://doi.org/10.1146/annurevenviron-021810-094524

Chen, S., J. C. Pernetta, and A. M. Duda. 2013. Towards a new paradigm for transboundary water governance: implementing regional frameworks through local actions. Ocean \& Coastal Management 85(B):244-256. https://doi.org/10.1016/j.

ocecoaman.2012.10.019

Chiovitti, R. F. and N. Piran. 2003. Rigour and grounded theory research. Journal of Advanced Nursing 44(4):427-435. https://doi. org/10.1046/j.0309-2402.2003.02822.x

Columbia Basin Tribes and First Nations. 2015. Fish passage \& reintroduction into the U.S. \& Canadian upper Columbia basin. Canadian Columbia River Inter-Tribal Fisheries Commission, Cranbrook, Canada. [online] URL: http://ccrifc.org/cms/wpcontent/uploads/2015/10/Fish Passage and Reintroduction into the US And_Canadian_Upper_Columbia_River4.pdf

Columbia Basin Trust and Northwest Power and Conservation Council. 2011. Memorandum of understanding and cooperation. Northwest Power and Conservation Council, Portland, Oregon, USA. [online] URL: https://www.nwcouncil.org/ media/34741/2011MOUwithCBT.pdf

Columbia River Treaty Local Governments' Committee and Columbia Basin Trust. 2015. Community engagement in Columbia basin hydro operations: an overview of current practices. Columbia River Treaty Local Governments' Committee, Fairmont Hot Springs, Canada. [online] URL: https://engage.gov.bc.ca/app/ uploads/sites/6/2014/05/2015-08-31-Overview-of-Community-Engagementin-Columbia-Basin-Hydro-Operations-August-2015.pdf

Conca, K. 2005. Governing water: contentious transnational politics and global institution building. MIT Press, Cambridge, Massachusetts, USA.

Cook, H., D. Benson, and L. Couldrick. 2016. Partnering for bioregionalism in England: a case study of the Westcountry Rivers Trust. Ecology and Society 21(2):38. http://dx.doi. org/10.5751/ES-08504-210238

Cook, S. E., M. J. Fisher, M. S. Andersson, J. Rubiano, and M. Giordano. 2009. Water, food and livelihoods in river basins. Water International 34(1):13-29. https://doi.org/10.1080/02508060802673860

Cope, M. 2010. Coding qualitative data. Pages 281-294 in I. Hay, editor. Qualitative research methods in human geography. Oxford University Press, Oxford, UK. 
Corbin, J., and A. Strauss. 2008. Basics of qualitative research: techniques and procedures for developing grounded theory. Third edition. Sage, Thousand Oaks, California, USA. https://doi. org/10.4135/9781452230153

Cosens, B. A. 2010. Transboundary river governance in the face of uncertainty: resilience theory and the Columbia River Treaty. Journal of Land, Resources and Environmental Law 30(2):229-266. [online] URL: http://epubs.utah.edu/index.php/jlrel/article/view/333

Cosens, B. A. 2013. Legitimacy, adaptation, and resilience in ecosystem management. Ecology and Society 18(1):3. http://dx. doi.org/10.5751/ES-05093-180103

Cosens, B. A., R. K. Craig, S. Hirsch, C. A. (T.) Arnold, M. H. Benson, D. A. DeCaro, A. S. Garmestani, H. Gosnell, J. Ruhl, and E. Schlager. 2017. The role of law in adaptive governance. Ecology and Society 22(1):30. https://doi.org/10.5751/ES-08731-220130

Cosens, B., L. Gunderson, C. Allen, and M. H. Benson. 2014. Identifying legal, ecological and governance obstacles, and opportunities for adapting to climate change. Sustainability 6 (4):2338-2356. https://doi.org/10.3390/su6042338

Cosens, B. A., and M. K. Williams. 2012. Resilience and water governance: adaptive governance in the Columbia River basin. Ecology and Society 17(4):3. http://dx.doi.org/10.5751/ES-04986-170403

da Silveira, A. R., and K. S. Richards. 2013. The link between polycentrism and adaptive capacity in river basin governance systems: insights from the River Rhine and the Zhujiang (Pearl River) basin. Annals of the Association of American Geographers 103(2):319-329. https://doi.org/10.1080/00045608.2013.754687

de Loë, R. 2009. Sharing the waters of the Red River basin: a review of options for transboundary water governance. Prepared for International Red River Board, International Joint Commission. Rob de loë Consulting Services, Guelph, Canada. [online] URL: http://www.ijc.org/files/publications/Sharing $\% 20$ the $\% 20$ Waters $\%$ 20of $\% 20$ the $\% 20$ Red $\% 20$ River $\% 20$ Basin.pdf

Denby, K., S. Movik, L. Mehta, and B. van Koppen. 2016. The 'trickle down' of IWRM: a case study of local-level realities in the Inkomati Water Management Area, South Africa. Water Alternatives 9(3):473-492. [online] URL: http://www.wateralternatives.org/index.php/alldoc/articles/vol9/v9issue3/333-a9-3-6/ $\underline{\text { file }}$

Dey, I. 1999. Grounding grounded theory: guidelines for qualitative inquiry. Academic Press, San Diego, California, USA.

Duit, A., V. Galaz, K. Eckerberg, and J. Ebbesson. 2010. Governance, complexity, and resilience. Global Environmental Change 20(3):363-368. https://doi.org/10.1016/j.gloenvcha.2010.04.006

Dunn, K. 2010. "Doing" qualitative research in human geography. Pages 99-137 in I. Hay, editor. Qualitative research methods in human geography. Third edition. Oxford University Press, Oxford, UK.

Earle, A., and M. Neal. 2017. Inclusive transboundary water governance. Pages 145-158 in E. Karar, editor. Freshwater governance for the 21 st century. Springer, Pretoria, South Africa.

Epstein, G., J. Pittman, S. M. Alexander, S. Berdej, T. Dyck, U. Kreitmair, K. J. Rathwell, S. Villamayor-Tomas, J. Vogt, and D.
Armitage. 2015. Institutional fit and the sustainability of socialecological systems. Current Opinion in Environmental Sustainability 14:34-40. https://doi.org/10.1016/j.cosust.2015.03.005

Flanagan, C., and M. Laituri. 2004. Local cultural knowledge and water resource management: the Wind River Indian Reservation. Environmental Management 33(2):262-270. https:// doi.org/10.1007/s00267-003-2894-9

Folke, C., T. Hahn, P. Olsson, and J. Norberg. 2005. Adaptive governance of social-ecological systems. Annual Review of Environment and Resources 30:441-473. https://doi.org/10.1146/ annurev.energy.30.050504.144511

Förster, J. J., L. Downsborough, and M. J. Chomba. 2017. When policy hits practice: structure, agency, and power in South African water governance. Society \& Natural Resources 30(4):521-536. https://doi.org/10.1080/08941920.2016.1268658

Galaz, V., B. Crona, H. Österblom, P. Olsson, and C. Folke. 2012. Polycentric systems and interacting planetary boundaries emerging governance of climate change-ocean acidificationmarine biodiversity. Ecological Economics 81:21-32. https://doi. org/10.1016/j.ecolecon.2011.11.012

Garmestani, A. S., and M. H. Benson. 2013. A framework for resilience-based governance of social-ecological systems. Ecology and Society 18(1):9. https://doi.org/10.5751/ES-05180-180109

Gerring, J. 2004. What is a case study and what is it good for? American Political Science Review 98(2):341-354. https://doi. org/10.1017/S0003055404001182

Granit, J., A. Jägerskog, A. Lindström, G. Björklund, A. Bullock, R. Löfgren, G. de Gooijer, and S. Pettigrew. 2012. Regional options for addressing the water, energy and food nexus in central Asia and the Aral Sea basin. International Journal of Water Resources Development 28(3):419-432. https://doi. org/10.1080/07900627.2012.684307

Gunderson, L., B. A. Cosens, B. C. Chaffin, C. A. (T.) Arnold, A. K. Fremier, A. S. Garmestani, R. K. Craig, H. Gosnell, H. E. Birge, C. R. Allen, M. H. Benson, R. R. Morrison, M. C. Stone, J. A. Hamm, K. Nemec, E. Schlager, and D. Llewellyn. 2017. Regime shifts and panarchies in regional scale social-ecological water systems. Ecology and Society 22(1):31. https://doi. org/10.5751/ES-08879-220131

Hamlet, A. F. 2011. Assessing water resources adaptive capacity to climate change impacts in the Pacific Northwest region of North America. Hydrology and Earth System Sciences 15 (5):1427-1443. https://doi.org/10.5194/hess-15-1427-2011

Hay, I. 2010. Qualitative research methods in human geography. Oxford University Press, Oxford, UK.

Heyns, P. S. V. H., M. J. Patrick, and A. R. Turton. 2008. Transboundary water resource management in Southern Africa: meeting the challenge of joint planning and management in the Orange River basin. International Journal of Water Resources Development 24(3):371-383. https://doi.org/10.1080/07900620802127317

Hill Clarvis, M., and N. L. Engle. 2015. Adaptive capacity of water governance arrangements: a comparative study of barriers and opportunities in Swiss and US states. Regional Environmental Change 15(3):517-527. https://doi.org/10.1007/s10113-013-0547y 
Hirsch, P., and A. Wyatt. 2004. Negotiating local livelihoods: scales of conflict in the Se San River basin. Asia Pacific Viewpoint 45(1):51-68. https://doi.org/10.1111/j.1467-8376.2004.00227.x

Hirt, P., and A. Sowards. 2012. The past and future of the Columbia River. Pages 115-136 in B. Cosens, editor. The Columbia River Treaty revisited: transboundary river governance in the face of uncertainty. Oregon State University Press, Corvallis, Oregon, USA.

Huitema, D., and S. Meijerink. 2017. The politics of river basin organizations: institutional design choices, coalitions, and consequences. Ecology and Society 22(2):42. https://doi. org/10.5751/ES-09409-220242

Huitema, D., E. Mostert, W. Egas, S. Moellenkamp, C. PahlWostl, and R. Yalcin. 2009. Adaptive water governance: assessing the institutional prescriptions of adaptive (co-)management from a governance perspective and defining a research agenda. Ecology and Society 14(1):26. https://doi.org/10.5751/ES-02827-140126

Hurlbert, M., and J. Gupta. 2016. Adaptive governance, uncertainty, and risk: policy framing and responses to climate change, drought, and flood. Risk Analysis 36(2):339-356. https:// doi.org/10.1111/risa. 12510

Jacobs, I. M. 2012a. A community in the Orange: the development of a multi-level water governance framework in the Orange-Senqu River basin in Southern Africa. International Environmental Agreements: Politics, Law and Economics 12(2):187-210. https:// doi.org/10.1007/s10784-012-9166-1

Jacobs, I. 2012b. The politics of water in Africa: norms, environmental regions and transboundary cooperation in the Orange-Senqu and Nile rivers. Continuum, London, UK.

Jordan, A. J., D. Huitema, M. Hildén, H. van Asselt, T. J. Rayner, J. J. Schoenefeld, J. Tosun, J. Forster, and E. L. Boasson. 2015. Emergence of polycentric climate governance and its future prospects. Nature Climate Change 5(11):977-982. https://doi. org/10.1038/nclimate2725

Khagram, S. 2004. Dams and development: transnational struggles for water and power. Cornell University Press, Ithaca, New York, USA. https://doi.org/10.7591/9781501727399

Knieper, C., and C. Pahl-Wostl. 2016. A comparative analysis of water governance, water management, and environmental performance in river basins. Water Resources Management 30 (7):2161-2177. https://doi.org/10.1007/s11269-016-1276-Z

Kranz, N., and A. Vorwerk. 2007. Public participation in transboundary water management. Paper submitted to the Amsterdam Conference on the Human Dimensions of Global Environmental Change. Ecologic Institute, Berlin, Germany. [online] URL: http://citeseerx.ist.psu.edu/viewdoc/download? $\underline{\text { doi }=10.1 .1 .565 .6950 \& \mathrm{rep}=\text { rep } 1 \& \text { type }=\mathrm{pdf}}$

Lankford, B., and N. Hepworth. 2010. The cathedral and the bazaar: monocentric and polycentric river basin management. Water Alternatives 3(1):82-101. [online] URL: http://www.wateralternatives.org/index.php/alldoc/articles/vol3/v3issue1/71-a3-1-5

Lebel, L., P. Garden, and M. Imamura. 2005. The politics of scale, position, and place in the governance of water resources in the Mekong region. Ecology and Society 10(2):18. [online] URL: http://www.ecologyandsociety.org/vol10/iss2/art18/
Lemos, M. C., and A. Agrawal. 2006. Environmental governance. Annual Review of Environment and Resources 31:297-325. https:// doi.org/10.1146/annurev.energy.31.042605.135621

Lesotho Highlands Development Authority. 2011. Agreement on Phase 2 of the Lesotho Highlands Water Project. Lesotho Highlands Development Authority, Maseru, Lesotho. [online]. URL: http://www.lhda.org.ls/phase2/documents/Legal\%20Framework/ Singed $\% 20$ Phase $\% 20 I I \% 20$ Agreement.pdf

Lesotho Highlands Development Authority. 2015. Lesotho Highlands Water Project: LHWP phase II compensation policy. Lesotho Highlands Development Authority, Maseru, Lesotho. [online] URL: http://www.lhda.org.ls/lhdaweb/Uploads/documents/ Governance/

LHWP $\% 20$ Phase $\% 20$ II $\% 20$ Compensation $\% 20$ Policy $\% 20(v 8 \% 201) \%$ 20Approved.pdf

Linton, J., and D. B. Brooks. 2011. Governance of transboundary aquifers: new challenges and new opportunities. Water International 36(5):606-618. https://doi.org/10.1080/02508060.2$\underline{011.599312}$

Maclean, K., and The Bana Yarralji Bubu Inc. 2015. Crossing cultural boundaries: integrating indigenous water knowledge into water governance through co-research in the Queensland wet tropics, Australia. Geoforum 59:142-152. https://doi.org/10.1016/ j.geoforum.2014.12.008

Marshall, G. 2007. Nesting, subsidiarity, and community-based environmental governance beyond the local scale. International Journal of the Commons 2(1):75-97. https://doi.org/10.18352/ ijc. 50

Marshall, G. R., and J. Alexandra. 2016. Institutional path dependence and environmental water recovery in Australia's Murray-Darling basin. Water Alternatives 9(3):679-703. [online] URL: http://www.water-alternatives.org/index.php/alldoc/articles/ vo19/v9issue3/323-a9-3-16/file

Marshall, G. R., D. Connell, and B. M. Taylor. 2013. Australia's Murray-Darling basin: a century of polycentric experiments in cross-border integration of water resources management. International Journal of Water Governance 1:197-218. [online] URL: http://www.ijwg.eu/pub/41/32438-13-17.pdf

McCaffrey, S., R. Paisley, L. de Silva, and A. Wolf. 2012. The Columbia River Treaty in 2014 and beyond: international experiences and lessons learned. Pages 365-382 in B. Cosens, editor. The Columbia River Treaty revisited: transboundary river governance in the face of uncertainty. Oregon State University Press, Corvallis, Oregon, USA.

McGinnis, M. D. editor. 1999. Polycentric governance and development: readings from the Workshop in Political Theory and Policy Analysis. University of Michigan Press, Ann Arbor, Michigan, USA.

McGinnis, M. D., and E. Ostrom. 2011. Reflections on Vincent Ostrom, public administration, and polycentricity. Public Administration Review 72(1):15-25. https://doi.org/10.1111/ j.1540-6210.2011.02488.x

McGinnis, M. V., editor. 1998. Bioregionalism. Routledge, London, UK. https://doi.org/10.4324/9780203984765 
McKinney, M. 2012. Managing transboundary natural resources: an assessment of the need to revise and update the Columbia River Treaty. Pages 84-114 in B. Cosens, editor. The Columbia River Treaty revisited: transboundary river governance in the face of uncertainty. Oregon State University Press, Corvallis, Oregon, USA.

McKinney, M. J., R. K. Paisley, and M. S. Stenovec. 2016. A sacred responsibility: governing the use of water and related resources in the international Columbia basin through the prism of Tribes and First Nations, Public Land and Resources Law Review 37:article 1. [online] URL: https://scholarship.law.umt. edu/cgi/viewcontent.cgi?referer=https://www.google.com/ $\underline{\text { \&httpsredir }=1 \& \text { article }=1479 \& \text { context }=\text { plrlr }}$

Meissner, R. 2015. Interest groups, water politics and governance: the case of the Lesotho Highlands Water Project. Springer, Heidelberg, Germany. http://dx.doi.org/10.1007/978-3-319-21130-5

Mirumachi, N. 2007. The politics of water transfer between South Africa and Lesotho: bilateral cooperation in the Lesotho Highlands water project. Water International 32(4):558-570. https://doi.org/10.1080/02508060.2007.9709688

Mirumachi, N., and E. Van Wyk. 2010. Cooperation at different scales: challenges for local and international water resource governance in South Africa. Geographical Journal 176(1):25-38. https://doi.org/10.1111/j.1475-4959.2009.00344.x

Mitchell, B., editor. 2013. Resource and environmental management. Second edition. Routledge, London, UK. https:// doi.org/10.4324/9781315847771

Moore, M.-L., S. von der Porten, R. Plummer, O. Brandes, and J. Baird. 2014. Water policy reform and innovation: a systematic review. Environmental Science \& Policy 38:263-271. https://doi. org/10.1016/j.envsci.2014.01.007

Morrison, T. H. 2017. Evolving polycentric governance of the Great Barrier Reef. Proceedings of the National Academy of Sciences 114(15):E3013-E3021. https://doi.org/10.1073/pnas.1620830114

Morrison, T. H., W. N. Adger, K. Brown, M. C. Lemos, D. Huitema, and T. P. Hughes. 2017. Mitigation and adaptation in polycentric systems: sources of power in the pursuit of collective goals. Wiley Interdisciplinary Reviews: Climate Change 8(5):e479. http://doi.org/10.1002/wcc.479

Mostert, E. 2012. Water management on the island of IJsselmonde 1000 to 1953: polycentric governance, adaptation, and petrification. Ecology and Society 17(3):12. http://dx.doi. org/10.5751/ES-04956-170312

Muller, M. 2012. Polycentric governance: water management in South Africa. Proceedings of the Institution of Civil Engineers Management, Procurement and Law 165(3):193-200. https://doi. org/10.1680/mpal.11.00018

Myint, T. 2012. Governing international rivers: polycentric politics in the Mekong and the Rhine. Edward Elgar, Cheltenham, UK.

Nagendra, H., and E. Ostrom. 2012. Polycentric governance of multifunctional forested landscapes. International Journal of the Commons 6(2):104-133. https://doi.org/10.18352/ijc.321
Norman, E. S. 2014. Governing transboundary waters: Canada, the United States, and indigenous communities. Routledge, London, UK. https://doi.org/10.4324/9780203781456

Norman, E., and K. Bakker. 2005. Drivers and barriers of cooperation in transboundary water governance: a case study of western Canada and the United States. Report to the Walter and Duncan Gordon Foundation, Toronto, Canada. [online] URL: http://watergovernance.sites.olt.ubc.ca/files/2010/06/

Gordon Foundation Transboundary Report.pdf

Norman, E. S., and K. Bakker. 2009. Transgressing scales: water governance across the Canada-U.S. borderland. Annals of the Association of American Geographers 99(1):99-117. https://doi. org/10.1080/00045600802317218

Norman, E. S., and K. Bakker. 2017. Transcending borders through postcolonial water governance? Indigenous water governance across the Canada-US border. Pages 139-157 in S. Renzetti and D. Dupont, editors. Water policy and governance in Canada. Springer, Cham, Switzerland. https://doi. org/10.1007/978-3-319-42806-2 8

North, D. C. 1991. Institutions. Journal of Economic Perspectives 5(1):97-112. https://doi.org/10.1257/jep.5.1.97

Northwest Power and Conservation Council. 2015. Memorandum. Northwest Power and Conservation Council, Portland, Oregon, USA. [online] URL: https://www.nwcouncil.org/media/7149440/4. pdf

Osborn, R. P. 2012. Climate change and the Columbia River Treaty. Washington Journal of Environmental Law and Policy 2 (1):75-123. [online] URL: http://digital.law.washington.edu/ dspace-law/bitstream/handle/1773.1/1148/2WJELP075.pdf?sequence=1

Ostrom, E. 1990. Governing the commons: the evolution of institutions for collective action. Cambridge University Press, Cambridge, UK.

Ostrom, E. 1999. Coping with tragedies of the commons. Annual Review of Political Science 2:493-535. https://doi.org/10.1146/ annurev.polisci.2.1.493

Ostrom, E. 2009. A polycentric approach for coping with climate change. Policy Research working paper WPS 5095. World Bank, Washington, D.C., USA. [online] URL: http://documents. worldbank.org/curated/en/480171468315567893/A-polycentric-approachfor-coping-with-climate-change

Ostrom, E. 2010. Polycentric systems for coping with collective action and global environmental change. Global Environmental Change 20(4):550-557. https://doi.org/10.1016/j.gloenvcha.2010.07.004

Ostrom, V., C. M. Tiebout, and R. Warren. 1961. The organization of government in metropolitan areas: a theoretical inquiry. American Political Science Review 55(4):831-842. https:// doi.org/10.1017/S0003055400125973

Pahl-Wostl, C. 2017. An evolutionary perspective on water governance: from understanding to transformation. Water Resources Management 31(10):2917-2932. https://doi.org/10.1007/ $\underline{\text { s11269-017-1727-1 }}$

Pahl-Wostl, C., G. Holtz, B. Kastens, and C. Knieper. 2010. Analyzing complex water governance regimes: the management 
and transition framework. Environmental Science and Policy 13 (7):571-581. https://doi.org/10.1016/j.envsci.2010.08.006

Pahl-Wostl, C., and C. Knieper. 2014. The capacity of water governance to deal with the climate change adaptation challenge: using fuzzy set qualitative comparative analysis to distinguish between polycentric, fragmented and centralized regimes. Global Environmental Change 29:139-154. https://doi.org/10.1016/j. gloenvcha.2014.09.003

Pahl-Wostl, C., L. Lebel, C. Knieper, and E. Nikitina. 2012. From applying panaceas to mastering complexity: toward adaptive water governance in river basins. Environmental Science and Policy 23:24-34. https://doi.org/10.1016/j.envsci.2012.07.014

Province of British Columbia. 2013. Appendix B: operations on the Columbia River - relationship between Columbia River Treaty, Non Treaty Storage Agreement, and water use plans. Province of British Columbia, Victoria, Canada. [online] URL: https:// engage.gov.bc.ca/app/uploads/sites/6/2012/07/Appendix-B-Operationson-the-Columbia-River-Relationship-between-CRT-NTSA-andWUPs-FINAL.pdf

Raadgever, G. T., E. Mostert, N. Kranz, E. Interwies, and J. G. Timmerman. 2008. Assessing management regimes in transboundary river basins: Do they support adaptive management? Ecology and Society 13(1):14. [online] URL: http:// www.ecologyandsociety.org/vol13/iss1/art14/

Reed, M. G., and S. Bruyneel. 2010. Rescaling environmental governance, rethinking the state: a three-dimensional review. Progress in Human Geography 34(5):646-653. https://doi. org/10.1177/0309132509354836

Rijke, J., M. Farrelly, R. Brown, and C. Zevenbergen. 2013. Configuring transformative governance to enhance resilient urban water systems. Environmental Science \& Policy 25:62-72. https://doi.org/10.1016/j.envsci.2012.09.012

Salet, W., and F. Savini. 2015. The political governance of urban peripheries. Environment and Planning C: Politics and Space33 (3):448-456. https://doi.org/10.1177/0263774X15594052

Sbaraini, A., S. M. Carter, R. W. Evans, and A. Blinkhorn. 2011. How to do a grounded theory study: a worked example of a study of dental practices. BMC Medical Research Methodology 11:128. https://doi.org/10.1186/1471-2288-11-128

Scholte, J. A. 2005. Globalization: a critical introduction. Second edition. Palgrave Macmillan, Basingstoke, UK.

Schreiber, R. S. 2001. The "how to" of grounded theory. Pages 55-81 in R. S. Schreiber and P. N. Stern, editors. Using grounded theory in nursing. Springer, New York, New York, USA.

Simonsen, S. H., R. Biggs, M. Schlüter, M. Schoon, E. Bohensky, G. Cundill, V. Dakos, T. Daw, K. Kotschy, A. Leitch, A. Quinlan, G. Peterson, and F. Moberg. 2014. Applying resilience thinking: seven principles for building resilience in social-ecological systems. Stockholm Resilience Centre, Stockholm, Sweden. [online] URL: http://www.stockholmresilience.org/download/18.10119fc11455$\underline{\mathrm{d} 3 \mathrm{c} 557 \mathrm{~d} 6928 / 1398150799790 / \mathrm{SRC}+\text { Applying+Resilience+final.pdf }}$

Sneddon, C., and C. Fox. 2007. Power, development, and institutional change: participatory governance in the lower
Mekong basin. World Development 35(12):2161-2181. https://doi. org/10.1016/j.worlddev.2007.02.002

Strauss, A., and J. Corbin. 1994. Grounded theory methodology: an overview. Pages 273-285 in N. Denzin and Y. Lincoln, editors. Handbook of qualitative research. Sage, Thousand Oaks, California, USA.

Suhardiman, D., M. Giordano, and F. Molle. 2012. Scalar disconnect: the logic of transboundary water governance in the Mekong. Society and Natural Resources 25(6):572-586. https:// doi.org/10.1080/08941920.2011.604398

Tarlock, A. D. 2000. Putting rivers back in the landscape: the revival of watershed management in the United States. Hastings West-Northwest Journal of Environmental Law and Policy 167 (2):167-198.

Tarlock, A. D., and P. Wouters. 2007. Are shared benefits of international waters an equitable apportionment? Colorado Journal of International Environmental Law and Policy 18 (3):523-536.

Thiel, A. 2015. Constitutional state structure and scalar reorganization of natural resource governance: the transformation of polycentric water governance in Spain, Portugal and Germany. Land Use Policy 45:176-188. https://doi.org/10.1016/j. landusepol.2015.01.012

Thiel, A. 2016. The polycentricity approach and the research challenges confronting environmental governance. THESys Discussion Paper 2016-1. Humboldt-Universitat zu Berlin, Berlin, Germany. [online] URL: https:/edoc.hu-berlin.de/ bitstream/handle/18452/3784/1.pdf? sequence $=1$

Turton, A. 2003. An overview of the hydropolitical dynamics of the Orange River basin. Pages 136-163 in M. Nakayama, editor. International waters in southern Africa. United Nations University Press, Tokyo, Japan. [online] URL: https://collections.unu.edu/ eserv/UNU:2428/nLib9280810774.pdf

Turton, A., and N. Funke. 2008. Hydro-hegemony in the context of the Orange River basin. Water Policy 10(52):51-69. https://doi. org/10.2166/wp.2008.207

von der Porten, S., and R. de Loë. 2013. Water governance and indigenous governance: towards a synthesis. Indigenous Policy Journal 23(4):148. [online] URL: http://www.indigenouspolicy. org/index.php/ipj/article/view/148

Vörösmarty, C. J., P. Green, J. Salisbury, R. B. Lammers. 2000. Global water resources: vulnerability from climate change and population growth. Science 289(5477):284-288. https://doi. org/10.1126/science.289.5477.284

Walker, B., and D. Salt. 2012. Resilience practice: building capacity to absorb disturbance and maintain function. Island Press, Washington, D.C., USA.

Warner, J. F., P. Wester, and J. Hoogesteger. 2014. Struggling with scales: revisiting the boundaries of river basin management. Wiley Interdisciplinary Reviews Water 1(5):469-481. https://doi. org/10.1002/wat2.1035 